\title{
OPTIMAL POOLING IN CLAIMS RESOLUTION FACILITIES
}

\author{
IAN AYRes* \\ I \\ INTRODUCTION
}

The various claims resolution facilities discussed in this symposium exhibit a number of distinctive qualities and governing principles. A common characteristic of many of these facilities, however, is an attempt to avoid the litigation costs of individualized proof of damages by channeling mass tort claims into rough categories for compensation. All claimants within a particular category receive similar compensation, even though they might be able to prove disparate damages through litigation. This article seeks to analyze the efficiency of pooling disparate claims through the categorical compensation of claims facilities.

An efficiency standard for evaluating tort law usually focuses on the ability of the legal rules to induce efficient levels of precaution; the costs of implementing the rules are relegated to a second order of importance. ${ }^{1}$ But this standard often is inapplicable to claims resolution facilities because many of the settlements that establish the facilities place an absolute cap on the defendant's liability. Ken Feinberg, trustee of the Dalkon Shield Claimants Trust, stressed the importance of such caps to the feasibility of establishing claims facilities:

The breakthrough in Agent Orange ... and the breakthrough in Dalkon Shield was a court imposed cap on liability. That gives the company total peace . . . That is why, once the companies put the money in, they disappeared. ${ }^{2}$

Copyright $\mathbb{C} 1990$ by Law and Contemporary Problems

- Research Fellow, American Bar Foundation; Assistant Professor, Northwestern University School of Law.

David Van Zandt provided helpful comments.

1. See, for example, John Prather Brown, Toward an Economic Theory of Liability, $2 \mathrm{~J}$ Legal Stud 323 (1973). When different rules induce equivalent levels of care, however, the cost of implementation is at times argued to be decisive in determining the efficiency of a particular rule. For example, Landes and Posner have argued that both contributory negligence and comparative negligence regimes will induce efficient precaution, but that contributory negligence is cheaper to enforce and therefore more efficient. William M. Landes \& Richard A. Posner, The Economic Structure of Tort Law 201-04 (1987).

2. Kenneth R. Feinberg, Transcript of Conference on Mass Settlements of Mass Torts, Tape 6 at 8 (April 28, 1989) (speech at conference on Mass Settlements of Mass Torts at Research Triangle Park, North Carolina, April 28-29, 1989; copy of transcript on file at Duke University School of Law) ("Transcript"). See also Kenneth R. Feinberg, The Dalkon Shield Claimants Trust, 53 L \& Contemp Probs 79 (Autumn 1990). 
Even if aggregate caps are not imposed by judicial fiat, they will be imposed by de facto economic fiat whenever the total liabilities of the defendant corporation exceed its net assets.

Because the deterrent effect of tort law turns primarily on a defendant's total liability, aggregate caps on damages shift the focus away from inducing efficient precaution to a concern with the cost of implementation. The most efficient way to distribute damage awards is to minimize the transaction costs in compensating victims. A large component of the transaction costs in compensating mass tort victims concerns the cost of individualized proof of damage and causation. Categorical compensation systems of claims facilities have the potential to increase dramatically the percentage of the defendant's aggregate damages that is actually paid to mass tort victims.

Categorical compensation of mass tort victims is likely to be Kaldor-Hicks efficient $^{3}$ relative to traditional individualized litigation, because such a distribution system will increase the average compensation for victims. It may be difficult, however, to construct categorical compensation packages that are also Pareto-efficient relative to litigation. 4 The pooling of dissimilar victims into dissimilar categories often results in some claimants receiving less damages from a claims facility than from litigation. This will be especially true if categorical compensation systems induce claimants to file frivolous actions that dilute the average compensation in the pool.

The adverse selection of frivolous claimants represents an important transaction cost of claims facilities that non-frivolous claimants must bear. ${ }^{5}$ These adverse selection costs, in a sense, substitute for the litigation costs of individualized proof of causation and damage. Claims facilities are most likely to be Pareto-efficient when the adverse selection costs of claims facilities are less than the litigation costs of proof.

When categorical compensation is not Pareto-efficient, undercompensated claimants will attempt to separate from the pool through litigation. For this reason, claims facilities may face significant "participation constraints" in channeling claimants to lower-cost categorical pools. In some situations, forced pooling, which denies plaintiffs the option of individualized litigation, may be welfare enhancing.

This article is written in two parts. Part II presents a simple model of categorical compensation to show when claims facilities are likely to be feasible and efficient. Part III extends the model to "partial pooling" and compares these models to the facilities discussed in this symposium. The

3. A policy is Kaldor-Hicks efficient if the "winners" could potentially compensate the "losers" so that no one in society suffers a welfare loss. Categorical compensation, which increases the average level of compensation, is likely to be Kaldor-Hicks efficient because those victims who receive less from a claims facility than from litigation could potentially be compensated by those who made more. Richard Posner, Economic Analysis of Law 12-14 (Little, Brown, 3d ed 1986).

4. The standard of Pareto efficiency would require that claimants receive less from a claims facility than from litigation.

5. "Adverse selection" refers to a process by which offers are made to nonhomogeneous people, but only the relatively "adverse" people tend to accept (or "self-select"). 
conclusion, in a more discursive fashion, suggests limits for this economic analysis and areas for further research.

\section{II}

\section{A Model of Categorical Compensation}

An economic case for the categorical compensation of claims can be made using an extremely simplified model of mass torts. ${ }^{6}$ Assume that there are $N$ number of mass tort claimants that are of two types. To put the model most provocatively, assume that the first type has a non-frivolous claim with damages of $D$ and that the second type has a frivolous claim with zero damages. ${ }^{7}$ Also assume that the individual plaintiffs know their type but that the defendant initially knows only that $\alpha$ percent of all plaintiffs have nonfrivolous claims, while $[1-\alpha]$ percent have frivolous claims.

Further assume plaintiffs incur costs of $C_{\mathrm{p}}$ and the defendant incurs costs of $C_{\mathrm{d}}$ if the case goes to trial. If cases go to trial, only non-frivolous plaintiffs recover $D$. A claims facility, however, pools the two types of plaintiffs together and offers all plaintiffs the average damages of $\alpha(D)$. The claims facility costs the defendant $C_{\mathrm{f}}$ per claim to administer.

An extensive form version of this "game" is presented in Figure 1.8 The informational asymmetry of the defendant's not knowing the plaintiff's type is modelled by Nature $(N)$ making the first move of the game. Nature chooses whether a particular plaintiff has a frivolous claim. The defendant, however, cannot observe Nature's choice at the time it decides whether to set up a claims facility (to make categorical offers of $\alpha$ ). The defendant's ignorance is depicted in Figure 1 by the dashed lines surrounding the defendant's decision nodes $D_{1}$ and $D_{2}$.

If the defendant fails to establish a claims facility, the claimant must choose whether or not to try the case. If the defendant does establish a claims facility to make categorical offers, the plaintiff must choose whether to accept the

6. The model described is similar to other models of pooling and separating equilibria found in a growing law and economics literature. See Ian Ayres \& Robert Gertner, Filling Gaps in Incomplete Contracts: An Economic Theory of Default Rules, 99 Yale L J 87 (1989); Alan Schwartz, A Theory of Loan Priorities, 18 J Legal Stud 209 (1989); Joseph P. Farrell \& Carl Shapiro, Optimal Contracts with Lock-In, 79 Am Econ Rev 51 (1989); Michael Rothschild \& Joseph E. Stiglitz, Equilibrium in Competitive Insurance Markets: An Essay on the Economics of Imperfect Information, 90 Q J Econ 629 (1976); Lucian A. Bebchuk \& Steven Shavell, Information and the Scope of Liability for Unusual Damages from Breach of Contract (March 1983) (unpublished manuscript on file with author).

7. In the next section, this assumption will be relaxed to allow plaintiffs to have a range of damages.

The amount of récoverable damages elides issues of injury and causation because under traditional tort law plaintiffs can only recover for injury caused by defendant's negligence. These damages are the amounts that would be awarded in traditional law suits. As discussed below, the amounts awarded in claims facilities may be different.

8. An explanation of extensive form representations can be found in Ian Ayres, Playing Games with the Law, 42 Stan L Rev 1291 (1990). See also Eric Rasmusen, Games and Information: An Introduction to Game Theory (1989) ("Cames and Information"). The following claims facility game is similar to settlement games with asymmetric information. See Robert Cooter \& Daniel L. Rubinfeld, Economic Analysis of Legal Disputes and Their Resolution, 27 J Econ Lit 1067 (1989); I.P.L. P'ng, Strategic Behavior in Suit, Settlement and Trial, 14 Bell J Econ 539 (1983). 
Figure 1

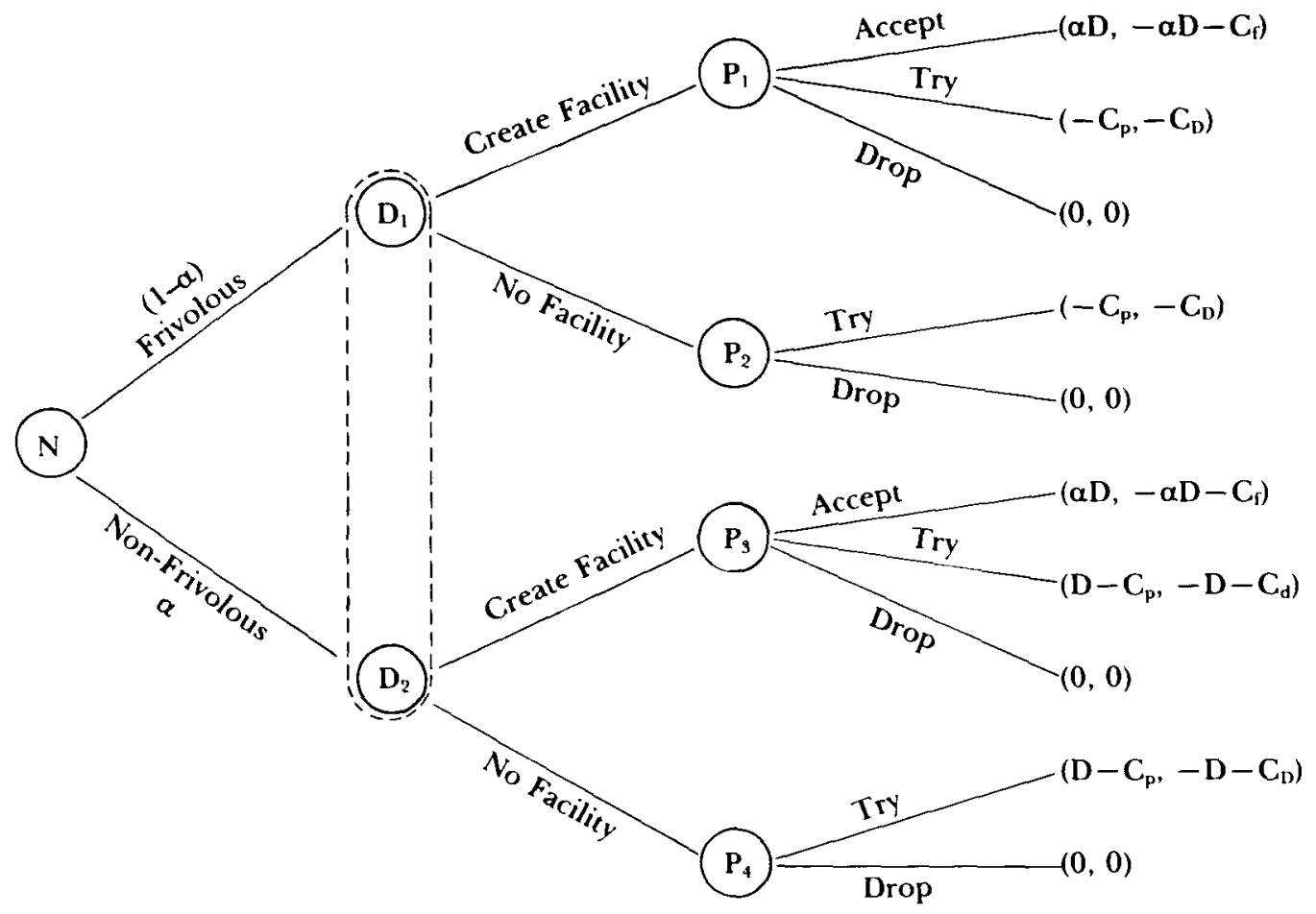

PAYOFFS: (PLAINTIFF, DEFENDANT)
(N):
NATURE'S DECISION NODE
Di:
DEFENDANT'S DECISION NODES
$\mathbf{P}_{i}$ :
PLAINTIFF'S DECISION NODES

offer or to opt out and try the case. ${ }^{9}$ The payoffs associated with different outcomes are represented in parentheses at the far right of Figure 1.

With these highly stylized assumptions, it is possible to show that a claims facility may be successful at efficiently pooling claims for disparate types of plaintiffs. ${ }^{10}$ If all plaintiffs accept the claims facility's categorical offer, the payoffs for the different parties can be summarized:

$$
\begin{array}{ll}
\text { Non-frivolous Claimant } & \alpha(D) \\
\text { Frivolous Claimant } & \alpha(D) \\
\text { Defendant } & -\left[\alpha(D)+C_{\mathrm{f}}\right] N .
\end{array}
$$

9. Theoretically, a claimant might choose to drop a case rather than accept or settle. But the claimant's zero payoff of dropping a case will be strictly less than his or her payoff for accepting a claims facility offer, so that the inferior (or "dominated") strategy choice of dropping can be eliminated from nodes $P_{1}$ and $P_{3}$.

10. It should be stressed that the assumption of only one compensation category is not important to the analysis so long as claimants cannot choose between different compensation categories (for example, in the Agent Orange claims facility, claimants applied for a particular disability category). There may be many other compensation categories for many other types of plaintiffs. This single category model can be viewed as analyzing the equilibrium behavior of one claimant category within a larger system of categories. 
A pooling equilibrium will be reached if none of the parties has an incentive to opt instead for individual litigation. Litigation is a "separating" device in that the defendant discovers the type of each claimant through the process of proof and treats the claimants accordingly. ${ }^{11}$ In a separating equilibrium, non-frivolous claimants would try their suits and frivolous claimants would drop their suits. The payoffs for a separating equilibrium would be:

$$
\begin{array}{ll}
\text { Non-frivolous Claimant } & D-C_{\mathrm{p}} \\
\text { Frivolous Claimant } & 0 \\
\text { Defendant } & -\left[\alpha(D)+C_{\mathrm{d}}\right] \alpha N .
\end{array}
$$

Claims facilities employing categorical compensation must overcome two participation constraints if the pooling equilibrium is to be reached. To assure the participation of non-frivolous claimants, the pooling payoffs must be higher than the separating payoffs:

$$
\alpha(D)>D-C_{\mathrm{p}}
$$

which implies:

(1) $C_{\mathrm{p}}>(1-\alpha) D$.

This is the participation constraint for non-frivolous claimants. Figure $1 \mathrm{dem}$ onstrates that if inequality (1) holds, then a non-frivolous claimant (at node $P_{3}$ ) will accept the offer of the claims facility rather than opt to try the case. Inequality (1) insures that both frivolous and non-frivolous claimants will choose to accept the claims facility offer. This inequality represents an important hurdle for the feasibility of claims facilities. The right-hand side of the inequality, $(1-\alpha) D$, represents the adverse selection costs that frivolous suits impose on the non-frivolous claimants. Pooling will be possible only if the adverse selection costs are lower than the litigation costs of proving that your claim is non-frivolous. The inequality implies that pooling equilibria of categorical compensation are more likely to be stable when:

(A) the plaintiff's cost of litigation $\left(C_{\mathrm{p}}\right)$ is large relative to expected damages $(D)$, and

(B) the percentage of frivolous claims $(1-\alpha)$ is low.

Even though the non-frivolous claimants could distinguish themselves by rejecting claims facility offers and demanding individual litigation, when inequality (1) holds, the non-frivolous claimants prefer to accept the offers and let the frivolous claimants "free ride" on the compensation pool. Inequality (1) embodies then the common sense wisdom that some flies are too small to swat. ${ }^{12}$

11. Indeed, if frivolous claimants were denied the option of accepting the categorical compensation (of $\alpha(D)$ ), they would drop the suit before trial, knowing that they would incur trial costs without hope of recovering damages. This analysis is borne out in Figure 1 by the fact that the frivolous claimant's payoff for dropping a suit $(0)$ is better than his or her payoff for trying a frivolous suit $\left(-C_{\mathrm{p}}\right)$.

12. Note that frivolous claimants would never opt out of the insurance pool. Opting for individual litigation would be a costly proposition, so that their second best alternative would be merely dropping the suit, which is clearly inferior to accepting categorical compensation. 
To assure the participation of the defendant, claims facilities must also be structured so that a defendant's payoffs are higher (that is, the costs to defendant are lower) through the pooled equilibrium than through litigation:

$$
\left[\alpha(D)+C_{\mathrm{f}}\right] N<\left[(D)+C_{\mathrm{d}}\right] \alpha N
$$

which implies:

(2) $C_{\mathrm{f}}<\alpha C_{\mathrm{d}}$.

Inequality (2) represents the defendant's participation constraint. The defendant's participation in a claims facility turns largely on the cost savings in processing the categorical claims compared to the costs of litigation. As inequality (2) reveals, there will be more claims under a pooling approach, because the frivolous claimants must be processed as well. Defendants' participation in categorical compensation will be more likely when:

(A) as above, the percentage of frivolous claims $(1-\alpha)$ is low, and

(B) the costs of processing categorical claims $\left(C_{\mathrm{f}}\right)$ is cheaper than the costs of litigation $\left(\alpha C_{\mathrm{d}}\right)$.

A separating equilibrium, in which the non-frivolous claimants try their claims and the frivolous claimants drop their claims, will occur if either of the participation constraints contained in inequalities (1) and (2) is violated. Separation will occur because either non-frivolous claimants prefer suit to settlement (violating inequality (1)), or defendants prefer litigating the smaller number of non-frivolous claims (violating inequality (2)).

The feasibility of claims facilities and pooled categorical compensation is distinct, however, from their efficiency. There may be situations in which inefficient separation occurs because the interests of the individual parties diverge from society's interest. A pooling equilibrium will only be wealth-maximizing relative to a separating equilibrium if the costs of processing both the frivolous and non-frivolous claims are less than the total social costs of litigating the non-frivolous claims:

$$
N C_{\mathrm{f}}<\alpha N\left(C_{\mathrm{d}}+C_{\mathrm{p}}\right)
$$

or, dividing by $N$ :

(3) $C_{\mathrm{f}}<\alpha\left(C_{\mathrm{d}}+C_{\mathrm{p}}\right)$.

Yet this standard for efficient pooling is not mandated by either participation constraint. Comparing inequalities (2) and (3), one finds that there are three possible relationships between the costs of processing facility claims $\left(C_{\mathrm{f}}\right)$ and the costs of litigation $\left(C_{\mathrm{d}}\right.$ and $\left.C_{\mathrm{p}}\right)$ :
(a) Efficient Pooling
$C_{\mathrm{f}}<\alpha C_{\mathrm{d}}$
(b) Inefficient Separating
$\alpha C_{\mathrm{d}}<C_{\mathrm{f}}<\alpha\left(C_{\mathrm{d}}+C_{\mathrm{p}}\right)$
(c) Efficient Separating
$\alpha\left(C_{\mathrm{d}}+C_{\mathrm{p}}\right)<C_{\mathrm{f}}$.

In region (a), when claims facility processing is sufficiently cheap, both inequalities (2) and (3) are satisfied so that pooling is both feasible and efficient. Similarly, for parameters in region (c), the preference of defendants for separation (violation of inequality (2)) coincides with the wealth-maximizing choice. In region (b), however, inefficient separation will result because the 
defendant's preference for separation diverges from the social preference for pooling. ${ }^{13}$ The defendant fails to internalize the plaintiff's costs of litigation when deciding whether to participate. ${ }^{14}$ Defendants consequently may opt for litigation (when inequality (2) is violated) even though the costs of the claims facility is less than the total cost of litigation.

The existence of region (b) demonstrates that efficient pooling might not always be feasible in the sense of satisfying the participation constraints. Even wealth-maximizing claims facilities may be unobtainable if the defendants and plaintiffs retain the option of litigation. When efficient voluntary pools are unobtainable, efficiency-minded regulators might seek to impose mandatory or enforced pooling. ${ }^{15}$ Under enforced pooling, the government mandates that parties cannot opt out of the pool for private litigation. Government regulation eliminates the participation constraint.

From the foregoing analysis, enforced pooling is most likely to be appropriate (as in region (b)) when the party's participation constraint diverges significantly from the welfare-maximizing standard. If individual plaintiffs or defendants are opting for litigation when settlement would be cheaper, then lawmakers might rationally remove the litigation option. It should be stressed, however, that enforced pooling can lower social welfare if improperly imposed. For example, in region (c), enforced pooling would keep employers from choosing the socially efficient compensation scheme. Indeed, the possibility that individual claimants will opt inefficiently for litigation might lead to the more radical idea that enforced pools for torts should be constructed even when the adversary or aggravation is not identified. Yet this is just what happens under the workers' compensation claim. Workers' compensation goes beyond voluntary compensation schemes, which announce a settlement rate that can be rejected in preference for litigation.

In sum, claims facility compensation schemes can increase efficiency by substituting categorical compensation for individualized litigation. In some situations, the adverse selection of frivolous claims is more desirable than more targeted, but more costly, litigation. Participation constraints for both the claimants and the defendant, however, may eliminate even efficient forms of pooling and militate in favor of more interventionist forms of enforced government pooling.

13. This social preference for pooling assumes that the first participation constraint, inequality (1), is also satisfied. It is possible to show that inefficient separation may also be caused by divergences between inequalities (1) and (3). Plaintiffs may opt for litigation even though pooled categorical compensation would be cheaper.

14. The compensation game in Figure 1 could be alternatively modelled to allow defendant's payoffs to internalize these costs.

15. Eric Rasmusen points out how adverse selection costs may undermine efficient pooling of health insurance. Rasmusen notes that "when the price of insurance is appropriate for the average old person, healthier ones stop buying [, and t] $]$ he price must rise to keep profits non-negative." Games and Information at 196 (cited in note 8). He initially concludes: "[A]dverse selection is an argument for enforced pooling. If all old people are required to purchase government insurance (Medicare in the United States), then while the healthier of them may be worse off, the vast majority could be helped." Id. Rasmusen ultimately concludes that "the cure [of government intervention] might be worse than the disease." Id. 
III

\section{Extensions and Applications of the Model}

\section{A. The Possibility of Partial Pooling}

The simple model examined in the last section imposed a strong assumption by limiting claimants to either frivolous damages of zero $(O)$ or non-frivolous damages of $D$. This section relaxes this assumption by allowing claimants to have a range of damages from 0 to $D_{\mathrm{H}}$. Defendants continue to be initially ignorant of the amount of damages suffered by each claimant. Whereas before defendants knew only the percentage of frivolous and nonfrivolous claims, now defendants are assumed to know only that the claimants' damages are uniformly distributed between 0 and $D_{\mathrm{H}} .^{16}$ Varying plaintiffs' damages allows us to examine the possibility of partial pooling equilibria. In a partial pooling equilibrium, some of the plaintiffs accept the categorical (or pooled) offer of the claims facility, while other plaintiffs opt out (or separate) to litigate their individual claims. ${ }^{17}$

Assume that individual claimants have damages of $D_{\mathrm{i}}$. In a partial pooling equilibrium, there will exist a critical damage value, $D^{*}$, above which "highdamage" claimants will litigate and below which "low-damage" claimants will pool. If, as before, the claims facility's categorical offer represents the expected damages of the claimants that remain in the pool, then in equilibrium the claims facility should offer all claimants $D_{\mathrm{cf}}$ :

(4) $D_{\mathrm{cf}}=D^{*} / 2.18$

Equation (4) represents the expected damages of claimants who would accept the offer, because in equilibrium only claimants with damages less than $D^{*}$ would, by assumption, accept.

To show that a partial pooling equilibrium could exist, we must again check participation constraints. Claimants that opt for litigation receive damages of $D_{\mathrm{i}}-C_{\mathrm{p}}$, while pooling claimants receive $D_{\mathrm{cf}} . D^{*}$ can be derived by finding the size of damages that will make a claimant indifferent between separating and pooling:

$$
\begin{aligned}
& D^{*}-C_{\mathrm{p}}=D_{\mathrm{cf}}=D^{*} / 2 \\
& 2 D^{*}-2 C_{\mathrm{p}}=D^{*}
\end{aligned}
$$

(5) $D^{*}=2 C_{\mathrm{p}}$.

Equation (5) can be substituted into equation (4) to show that in a partial pooling equilibrium a claims facility (under these assumptions) will offer:

16. The uniform probability distribution assigns equal probability to any event occurring within the supported range. In this model, the probability that a plaintiff will have damages less than $x$ (where $0<x<D_{\mathrm{H}}$ ) is $x / D_{\mathrm{H}}$.

17. Partial pooling consequently entails partial separation. See Rasmusen, Games and Information at 209 (cited in note 8 ).

18. If claimants with damages below $D^{*}$ opt for the categorical damages of a claims facility, then the average damages of their claims will be $D^{*} / 2$ (since their claims are uniformly distributed and range between 0 and $D^{*}$ ). 
(6) $D_{\mathrm{cf}}=C_{\mathrm{p}}$.

Together, equations (5) and (6) reveal that the plaintiff's litigation costs $\left(C_{\mathrm{p}}\right)$ are crucial in preventing the partial pool from unraveling. Plaintiffs will remain in the pool only if the returns from litigation are no greater than the categorical offer. If the claims facility offers to pay damages equal to the costs that a plaintiff would incur in litigation, ${ }^{19}$ then claimants with damages less than these litigation costs $\left(D_{\mathrm{i}}<C_{\mathrm{p}}\right)$ would certainly accept the offer. Not only would these claimants receive more from the claims facility than from a favorable court judgment, but they also would avoid the costs of litigation. Moreover, even some claimants with damages higher than the claims facility offer $\left(2 C_{\mathrm{p}}<D_{\mathrm{i}}<C_{\mathrm{p}}\right)$ will accept the offer because they can increase their net payoffs by avoiding the costs of litigation. This pooling of claimants with damages between 0 and $2 C_{\mathrm{p}}$ with categorical compensation of $C_{\mathrm{p}}$ forces defendants to pay pooled claimants their expected damages and restricts the pool to claimants that gain by avoiding litigation.

As in the previous model, in order to achieve a partial pooling equilibrium, the participation constraints of the defendant must be satisfied as well. Without a claims facility, defendants would pay:

(7) $\left[C_{\mathrm{d}}+\frac{\left.\left(D_{\mathrm{H}}+C_{\mathrm{p}}\right)\right]}{2} \frac{\left[D_{\mathrm{H}}-C_{\mathrm{p}}\right.}{D_{\mathrm{H}}} N^{20}\right.$

With a claims facility and a partial pooling equilibrium, defendants would pay suing claimants:

(8) $\left.\left[C_{\mathrm{d}}+\frac{\left(D_{\mathrm{H}}+D^{*}\right)}{2}\right] \frac{\left[D_{\mathrm{H}}-D^{*}\right.}{D_{\mathrm{H}}}\right] N^{21}$

and would pay non-suing claimants who accepted the categorical offer $D_{\mathrm{cf}}$ :

19. The result in equation (6) that the offer of the claims facility is equal to the plaintiff's litigation cost is a by-product of the assumption that claimants' damages vary between 0 and $D_{\mathbf{H}}$. If, instead, claimants' damages vary between $D_{\mathrm{L}}$ and $D_{\mathrm{H}}$, then $D_{\mathrm{c}}$ would equal $D_{\mathrm{L}}+C_{\mathrm{p}}$.

20. Equation (7) can be explained in the following way. Without a claims facility, only claimants with damages greater than $C_{p}$ will find it profitable to sue, so that defendants will only incur costs related to a quantity of claims equaling:

$$
\left[\frac{D_{\mathrm{H}}-C_{\mathrm{p}}}{D_{\mathrm{H}}}\right]^{N}
$$

With regard to each of these claims, defendants must pay litigation costs of $C_{d}$ plus average damages of

$$
\frac{D_{\mathrm{H}}+C_{\mathrm{P}}}{2}
$$

21. With a claims facility and a partial pooling equilibrium, only claimants whose damages are greater than $D^{*}$ will find it profitable to opt for litigation, so that defendants will face suit by

$$
\left[\frac{D_{\mathrm{H}}-D^{*}}{D_{\mathrm{H}}}\right]^{N}
$$

litigants. The defendant's costs for these suits are analogous to the previous footnote. Defendant must pay litigation costs of $C_{\mathrm{d}}$ plus average damages of

$$
\frac{D_{\mathrm{H}}=D^{*}}{2}
$$


(9) $\left[C_{\mathrm{f}}+D_{\mathrm{cf}}\right]\left[\frac{D^{*}}{D_{\mathrm{H}}}\right] N .{ }^{22}$

Defendants would establish a claims facility only if the amount of total liability in expressions (8) and (9) is less than the amount of total liability in expression (7). With or without a claims facility, the defendants will incur the litigation costs and individualized damages for the high-damage claimants $\left(D_{i}\right.$ $\left.>D^{*}\right) .^{23}$ The difference in the defendants' total costs under the regimes is two-fold:

(A) without a claims facility, there are fewer claimants because claimants with lowdamages $\left(D_{\mathrm{i}}<C_{\mathrm{p}}\right)$ will not sue; and

(B) without a claims facility, the defendants will incur higher transaction costs for those claimants that do sue, because, by assumption, the costs of litigation are higher than the costs of processing facility claims $\left(C_{\mathrm{d}}>C_{\mathrm{f}}\right)$.

In deciding whether to establish a claims facility, the defendant must choose between compensating a larger group with lower transaction costs and compensating a smaller group with higher transaction costs. Algebraically, expressions (7), (8), and (9) can be manipulated to show that defendants will prefer a claims facility regime with a partial pool when:

(10) $C_{\mathrm{d}}+\left(3 C_{\mathrm{p}} / 2\right)-C_{\mathrm{f}} C_{\mathrm{p}}-C_{\mathrm{p}}{ }^{2}>0 .{ }^{24}$

As suggested above, a claims facility will be more desirable to defendants the larger the transaction cost savings $\left(C_{\mathrm{d}}-C_{\mathrm{f}}\right)$ and the smaller the moral hazard of low-damage claims $\left(D_{\mathrm{i}}<C_{\mathrm{p}}\right) \cdot{ }^{25}$

\section{B. The Models Meet the Stylized Facts of the Conference}

While the foregoing models are admittedly reductive and abstract, they capture several aspects of existing claims facilities and suggest ways that

22. In a partial pooling equilibrium

$$
\left[\frac{D^{*}}{\overline{D_{\mathrm{H}}}}\right]^{N}
$$

claimants opt for the categorical compensation of $D_{\mathrm{cf}}$. Defendant's costs are these categorical payments plus the costs of processing the claims $\left(C_{f}\right)$.

23. This can be seen algebraically in that expression (7) is a subset of expression (8) damages.

24. Expression (7) will be greater than expressions (8) and (9) when:

$$
\begin{aligned}
& \left.\left.\left[C_{\mathrm{d}}+\frac{\left(D_{\mathrm{H}}+C_{\mathrm{P}}\right)}{2}\right]\left[\frac{D_{\mathrm{H}}-C_{\mathrm{P}}}{D_{\mathrm{H}}}\right] N>\left[C_{\mathrm{d}}+\frac{\left(D_{\mathrm{H}}+D^{*}\right.}{2}\right)\right]\left[\frac{D_{\mathrm{H}}-D^{*}}{D_{\mathrm{H}}}\right] N+\left[C_{\mathrm{r}}+D_{c f}\right)\right]\left[D^{*}\right] N
\end{aligned}
$$

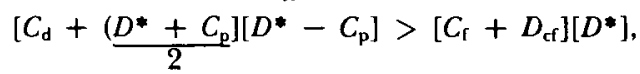

Substituting $D^{*}=2 C_{\mathrm{p}}$, and $D_{\mathrm{cf}}=C_{\mathrm{p}}$ :

$$
\begin{aligned}
& {\left[C_{\mathrm{d}}+\frac{\left.\left.\left(2 C_{\mathrm{p}}+C_{\mathrm{p}}\right)\right]\left[2 C_{\mathrm{p}}-C_{\mathrm{p}}\right]>\left[C_{\mathrm{f}}+C_{\mathrm{p}}\right)\right]\left[2 C_{\mathrm{p}}\right],}{2}\right.} \\
& {\left[C_{\mathrm{d}}+\frac{\left.\left.\left(3 C_{\mathrm{p}}\right)\right]>\left[C_{\mathrm{f}}+C_{\mathrm{p}}\right)\right]\left[C_{\mathrm{p}}\right],}{2}\right.}
\end{aligned}
$$

which can be simplified to inequality $(10)$ :

$C_{\mathrm{d}}+\left(3 C_{\mathrm{p}} / 2\right)-C_{\mathrm{p}} C_{\mathrm{p}}-C_{\mathrm{p}}^{2}>0$.

25. Without a claims facility, low-damage claimants $\left(D_{\mathrm{i}}<C_{\mathrm{p}}\right)$ would not file suit. These lowdamage claimants are able to free-ride on the categorical offers and avoid the costs of litigation. The lower the costs of litigation to plaintiffs, the smaller the size of this "moral hazard"(or free-riding), because more claimants would be willing to sue. 
claims facilities should be structured to meet both the demands of rational self-interest (embodied in the participation constraints) and the overall goal of improving social welfare (embodied by the efficiency norm of transaction cost minimization). This section examines in particular how the existing claims facilities have reacted to participation constraints and informational asymmetries.

1. Participation Constraints. In constructing a claims facility, participants need to be acutely aware of the participation constraints on both plaintiffs and defendants. As the models have indicated, forced pooling may be socially desirable in some situations. However, courts generally have been reluctant to eliminate plaintiffs' right to individualized litigation. For this reason, class actions for mass torts have been organized as "opt out" class actions under Federal Rule of Civil Procedure 23(b)(3), ${ }^{26}$ through which claimants retain the option of proceeding with individualized arbitration or trial (such as with Dalkon Shield and asbestos facilities).

In claims facility arrangements that retain the option of litigation, there will almost always be partial pooling in that some claimants will accept the prelitigation offers, while others will choose to incur the costs of litigation. The Dalkon Shield claims facility provides for a variety of dispute resolution options that allow claimants to pool at different levels according to the effort expended in proving their claims (ranging from short-form proof of damages, to longer tailored forms, to binding arbitration, to trial). And while the results of the foregoing algebraic models are meant to be impressionistic, the short-form categorical payment of $\$ 725$ for Dalkon Shield claimants ${ }^{27}$ resonates with the result of the partial pooling model suggesting that categorical compensation be limited to an amount approximating the plaintiff's cost of litigation.

The Agent Orange settlement is unique in that Judge Weinstein effectively created a forced pool. By dismissing the cases of approximately 400 veterans who had "opted out" of settlement, the Court eliminated the plaintiffs' ability to proceed with individualized proof of damages. The general danger of forced pools is that high-damage plaintiffs are forced to accept lower categorical awards of the claims facility pool. Accordingly, while forced pooling may benefit society by reducing the transaction costs of individualized litigation, this benefit may come at the detriment of high-damage claimants. ${ }^{28}$ Judge Weinstein had strong reasons, however, for imposing a forced pool on these claimants. Because the Court found that individual causation could not be proven, ${ }^{29}$ any amount spent by plaintiffs in trying to establish individual

26. Francis E. McGovern, The Alabama DDT Settlement Fund, 53 L \& Contemp Probs 61,63 (Autumn 1990).

27. Feinberg, $53 \mathrm{~L} \&$ Contemp Probs at 106 (cited in note 2).

28. The forced nature of the pool implies that it cannot be Pareto efficient, but at best KaldorHicks efficient.

29. Id at 100-04. See also Harvey P. Berman, The Agent Orange Veterans' Payment Program, 53 L \& Contemp Probs 49 (Autumn 1990). 
damages would have been a waste of social and individual resources. In other words, since no claimant had a legal right to compensation, the court did less harm to equity (or the Pareto efficiency criterion) by eliminating individualized proof of compensable injury.

Whether or not a forced pool eliminates the claimants' participation constraints, however, claims facility settlements still must satisfy the defendants' participation constraints. ${ }^{30}$ Indeed, the same reasoning that justifies Judge Weinstein's imposition of a forced pool makes it more difficult to understand why the defendants contributed more than $\$ 200$ million to the settlement. ${ }^{31}$ If the individual plaintiffs could not meet the causation requirement, the defendants presumably should have refused to settle, knowing that they would win at trial. Ken Feinberg, the special master in the case, suggests that settlements are "driven by an increasingly apparent political reality ... that society wants victims compensated and looks to the deep pocket to do it."32 Feinberg's quotation suggests that the defendants in this case might have feared that they would lose outside of litigation (via unfavorable legislation or a consumer backlash) if they did not make a substantial contribution to a settlement. Moreover, defendants might have narrowly benefitted from the settlement to the extent that the costs of defending the individual suits would have been larger than the costs of processing the claims. ${ }^{33}$

More generally, conference participants stressed the problem of frivolous claims in constructing feasible facilities. Ken Feinberg noted that there is "a wide gap between good cases and bad ones. And . . the wheat and the chaff are not easy to separate. . . I'm not sure there are really 192,000 cases in Dalkon shield. . . . I'm increasingly of the view that there are a lot less real cases." 34 Similarly, another speaker at the conference cited the problem of frivolous claims as justification for the $\$ 725$ compensation paid to short-form Dalkon Shield claimants:

Our feeling was that there was a substantial number of false positives. ... The model that was used in setting up [the $\$ 725$ option] was really the Hyatt skywalk case. You may remember that at the Hyatt Hotel in Kansas City the skywalk fell in a number of years ago, and more people filed suit than could have fit into every hotel in Kansas City. . . What the defendants did in that case was offer a thousand dollars to everybody as go away money. And from the [Dalkon Shield] survey that we did of the 8,000 women, we found [that with respect tol a very substantial number of women when they got their medical records, it was a Copper 7 or a Tatum T [brand IUD]. Or it turned out they really had not been using an IUD; it was some kind of other device. ${ }^{35}$

30. Courts might also force defendants to participate in a categorical payment scheme. Thus, forced pooling theoretically could apply to both sides of a dispute.

31. Berman, 53 L \& Contemp Probs at 50-51 (cited in note 29).

32. Feinberg, Transcript, Tape 6 at 5 (cited in note 2).

33. Yet, after a few individual plaintiffs lose their suits, it might not be a credible threat for other plaintiffs to continue incurring the costs of litigation in a lost cause.

34. Feinberg, Transcript, Tape 6 at 24 (cited in note 2).

35. Mark A. Peterson, Transcript, Tape 6 at 30 (cited in note 2). See also Mark A. Peterson, Giving Away Money: Comparative Comments on Claims Resolution Facilities, 53 L Contemp Probs 113 (Autumn 1990). 
As the models suggest, the prevalence of frivolous suits inhibits the ability of defendants to offer meaningful categorical compensation because claimants without legally compensable damages can fit within most short-form claimant pools. In the words of Ken Feinberg, "The wheat and the chaff are not easy to separate." As the free-riding of frivolous claimants reduces the average amount of categorical compensation that defendants can offer, more and more claimants will opt for more expensive forms of individualized proof.

Finally, in assessing whether defendants will be willing to participate in a claims facility, it may be important to account for heterogeneity among defendants. The dissolution of the original Asbestos Claims Facility and the creation of the Center for Claims Resolution can be seen as an effort to reduce this heterogeneity and to pool more similarly situated defendants. ${ }^{\mathbf{3 6}}$ Because the defendants' individual liability varied over different classes of cases, it was difficult to develop a cost-sharing formula that did not involve substantial cross-subsidization. Defendants, much like plaintiffs, will opt out of the pool if they feel that the costs of going it alone are likely to be smaller. Categorical compensation that forces individual defendants to pay a larger proportion than individualized litigation will likely be unsustainable. Devising cost-efficient pools of categorical compensation that are not susceptible to massive unraveling is the center of the claims facility movement.

2. Information Asymmetries. It is important to emphasize that the foregoing models have been games of asymmetric information in which the claimants know their damages but the defendants know only the probability distribution of damages. If information is distributed more symmetrically, then the unraveling effect of high-damage claimants opting for individualized proof is less likely to occur. In an extreme example, assume that neither claimants nor defendants know whether a class of claimants suffers from an asbestos-related cancer, but through a test costing $\$ 50,000$ per claimant to administer, they can find out. As long as the parties agree on the probability that the cancer is caused by asbestos, then settlement offers for the expected damages will be more sustainable because individual claimants will have no reason to opt for the more expensive proof (the $\$ 50,000$ test) via litigation. The simple implication of the model is that symmetric ignorance promotes categorical pooling.

An interesting application of this observation arose in the DDT litigation. The parties agreed to a categorical settlement system that turned in part on the amount of DDT found in each claimant's blood sample. However, the individual claimants were not informed of their DDT levels until after the settlement agreement had been entered and approved by the court. ${ }^{37}$ In this case, the claimants and their representatives (as well as the defendants) were in a sense bargaining behind a Rawlsian veil of ignorance by agreeing to abide

36. See generally Lawrence Fitzpatrick, The Center for Claims Resolution, 53 L \& Contemp Probs 13 (Autumn 1990)

37. McGovern, Transcript 7 at 12 (cited in note 2). 
by the categorical system before knowing their particular category of compensation. ${ }^{38}$

The algebraic models described above also assumed that both the claimants and the defendants knew the probability distribution of underlying damages (in the simple model, they knew the percentage of frivolous suits). If this assumption fails, the parties may have difficulty agreeing on the appropriate expected damages for various claimant categories. To make facilities viable, it may be necessary to audit random samples of claimants to determine with more intensive (and costly) scrutiny the distribution of damages for the larger population of claimants. This technique was implemented in the Dalkon Shield litigation in which the court appointed experts to examine a sample of 8,000 claims. ${ }^{39}$

The intuition that more symmetrically held information will support lower-cost pooling is contradicted, however, by the importance that asbestos defendants have placed on settlement secrecy. Lawrence Fitzpatrick, president and chief executive officer of the Center for Claims Resolution, repeatedly stressed that he was not at liberty to disclose per claim averages: "Our members, for fairly obvious reasons, consider those to be highly confidential." 40 Yet the reason for maintaining the secrecy of past settlements is not so obvious. Would claimants systematically overestimate the relative value of their claim compared to the average settlement if there were disclosure? Even if this were the case, disclosure would be advisable if claimants inferred especially high settlements from the defendants' silence. In sum, both the exogenous and, as here, endogenous informational structure of the negotiations will strongly influence the range of feasible settlements.

\section{IV}

\section{Conclusion}

The investments that plaintiffs make in litigation can be viewed in gametheoretic terms as a signalling process whereby meritorious claimants attempt to signal their worth to the courts. ${ }^{41}$ The recent movement away from individualized litigation toward categorical compensation systems in claims facilities can be viewed as a search for a more efficient signalling system. In many cases the costs of processing a claim in a facility is cheaper than

38. See generally John Rawls, $A$ Theory of Justice 136-42 (Harvard U Press, 1971). See also Francis E. McGovern, Foreword, 53 L \& Contemp Probs 1 (Autumn 1990).

39. This database was used not only to construct the categorical compensation options but also to estimate the total tort liability of A. H. Robins, Inc., for purposes of bankruptcy. Whether the sampling was sufficient is open to dispute. Feinberg reports that: The estimates presented to the court "ranged from $\$ 800$ million (suggested by Robins) to $\$ 7$ billion (suggested by the 'Claimants' Committee,' a group of attorneys who represented the Dalkon Shield plantiffs)." In the end, the court announced the total value of the claims as $\$ 2.475$ billion without setting forth the reasoning behind the decision. Feinberg, 53 L \& Contemp Probs at 103 (cited in note 2).

40. Lawrence Fitzpatrick, Transcript, Tape 1 at 24 (cited in note 2).

41. Daniel L. Rubinfeld \& David E. Sappington, Efficient Awards and Standards of Proof in Judicial Proceedings, 18 Rand J Econ 308 (1987). 
litigating the claim at trial. But to be effective, signals must be costly to fake. ${ }^{42}$ A central obstacle to establishing categorical systems is devising categories that are cheap to prove, but still costly to fake. Roughly hewn "grids" for compensation can dramatically reduce the cost of establishing a claim for valid claimants and thus potentially raise the proportion of liability that actually is used to compensate victims. But the same grids may invite frivolous or inflated claims, which reduce the signalling power of the system and undermine both the willingness of defendants to pay and the willingness of meritorious claimants to remain in the pool. As in other adjudicative areas, categorical compensation regimes are subject to Type 1 and Type 2 errors ${ }^{43}$ of under- and overcompensation. Increasing the costs of processing claims could reduce these costs, but could also reduce the advantage of claims facilities over traditional litigation.

This article has stressed the obstacles in developing sustainable claims facilities by focusing on the participation constraints for both claimants and defendants. The facilities examined in this conference provide strong evidence that these obstacles are not insurmountable. Indeed, when pooling of claimants into compensation categories is possible, there often may be discretion over the particular contours of the categories and division of compensation. When more than one type of categorical pooling is possible, participants will have self-interest in lobbying so that their most favorable pool is implemented. This type of conflict resembles the classic "battle of the sexes" game, in which a husband and wife prefer spending the evening together but disagree about which event to attend. ${ }^{44}$ Both claimants and defendants may prefer the more efficient pooling of a categorical system to the separation of individualized litigation, but differ as to what type of pooling system to implement. As with other bargaining games, if any of the participants hold out for too much of the pie, then all may have to forfeit the gains from entering into the pooling relation.

While this article has taken an economic perspective to predict selfinterested behavior and judge that behavior by an efficiency benchmark, its emphasis on the conditions for participation can be analyzed with other theories of human behavior and judged by other normative benchmarks. The central concern has been a sensitivity to the pooling and separating effects of claims facilities and the categorical compensation systems that they often employ. Historical data and socio-psychological theory can also inform these core issues. Indeed, some statements made at the conference or published in conference papers are clearly at odds with economic theory. Some of the statements may be mistaken, ${ }^{45}$ but others suggest the limits of economic

42. See Robert Frank, Passions Within Reason 99 (1988).

43. Type 1 and Type 2 errors refer respectively to the possibilities of compensating nonmeritorious claims and failing to compensate meritorious claims.

44. See Rasmusen, Games and Information at 34 (cited in note 8).

45. Examples of such statements include:

(1) At the conference, Lawrence Fitzpatrick emphasized that "the average verdict was . . about half the amount prior to the creation of the [Center for Claims Resolution] facility." Lawrence 
analysis. For example, Marianna Smith, Executive Director the Manville Personal Injury Settlement Trust, stressed the importance of settling cases well before trial is imminent: " $[\mathrm{O}]$ ne of the most significant issues facing the Trust is how it will avoid becoming driven to settle cases on the trial docket in lieu of settling claims waiting their turns in the FIFO queue." 46 Yet economic models of settlement do not suggest why waiting to settle would systematically disadvantage the defendant Trust in that case. Moreover, as discussed above, ${ }^{47}$ simple economic models do not predict that asbestos defendants would insist on keeping their settlement awards secret. Finally, economic models do not predict Manville's creation of its "have a heart fund" to pay victims whose claims "were not meritorious in the sense of the legal system, but from equity ... had some merits." 48 Accordingly, the recasting of the stylized facts in economic terms should not exclude noneconomic theories. But as in other areas of dispute resolution, when people fight over money, there is a role for economic analysis. ${ }^{49}$

Fitzpatrick, Transcript, Tape 1 at 16-17 (cited in note 2). Yet this statistic is misleading because the Center for Claims Resolution had fewer defendant participants than the prior Asbestos Claims Facility, so that the smaller verdicts might represent larger damages adjusted for the market share of the individual defendants.

(2) Fitzpatrick went on to argue that this trend toward lower awards was "a positive accomplishment on the part of the victims":

One of the real dangers of asbestos litigation is the runaway verdict. When you get a verdict of several million dollars in a given jurisdiction, it makes it difficult for a plaintiffs' attorney to convince the rest of his clients in that jurisdiction that they ought to accept reasonable settlement monies, particularly because these victims very often know each other quite well because they come from the same unions, work in the same shipyards.

Id. This argument, if anything, means that victims as a class are helped by a smaller dispersion in awards. But even his "runaway verdict" argument is based on a perverse form of irrationality. Few people with lottery tickets would feel better off if the grand prize were reduced.

(3) Ken Feimberg suggested that "there are cost savings in processing claims by tying together the investment management side with the claims facility side." Kenneth R. Feinberg, Transcript, Tape 6 at 16 (cited in note 2). Yet it is difficult to see why firms who invest the corpus of a trust would be better positioned to process the claims. If the market for subcontracting these two tasks were less competitive, there might be some room for anti-competitive "bundling" of the two tasks, but Feinberg himself understands that the market for investment management is rivalrous: "You'd be surprised how many blue chip companies are interested in Dalkon Shield's two and one-half billion dollar corpus." Id.

46. Marianna S. Smith, Resolving Asbestos Claims: The Manville Personal Injury Settlement Trust 12 (1989) (paper presented at Conference on Mass Settlements of Mass Torts at Durham, North Carolina, April 28-29, 1989). See also Marianna S. Smith, Resolving Asbestos Claims: The Manville Personal Injury Settlement Trust, 53 L \& Contemp Probs 27 (Autumn, 1990) (updated version of conference paper). At the conference, Smith reiterated this point, saying that: "One of the things that destroyed the [Asbestos Claims Facility] was the fact that they couldn't keep up with that court docket so they were always settling cases on that court house square." Marianna S. Smith, Transcript, Tape 1 at 47 (cited in note 2).

47. See text accompanying note 40 .

48. Gene Locks, Transcript, Tape 7 at 38 (cited in note 2).

49. The final comments at the conference may have expressed this too strongly: "[I]f anybody thinks that there is anything more than money or dollars or economics driving these mass tort cases, I suspect you're naive. It is the dollars and it is the expense." David Gross, Transcript, Tape 7 at 40 (cited in note 2). 